\title{
Two spotted spider mite (Tetranychus urticae, Koch) resistance to METI acaricides analysed in selected Polish apple orchards
}

\author{
Odporność przędziorka chmielowca (Tetranychus urticae, Koch) \\ na METI akarycydy analizowana w wybranych sadach jabłoniowych \\ w Polsce
}

Damian Gorzka, Remigiusz W. Olszak, Michał Hołdaj

\begin{abstract}
Summary
Two spotted spider mite (Tetranychus urticae, Koch) is one of important apple orchards pest. Some of the commonly used acaricides against motil stages of this pest are those from the METI group (mitochondrial electron transport inhibitors). The aim of the study was to evaluate the prevalence of the phenomenon of resistance in apple orchards in Poland. The mites collected in orchards located in different regions of country were tested in laboratory with registered compounds belonging to the METI acaricides (Magus 200 SC, Ortus 05 SC, Sanmite 20 WP). Some of the tested populations were characterized by a high resistance, comparable with the resistance of individuals from laboratory breeding resistant strain Akita.
\end{abstract}

Key words: Two spotted spider mite; Tetranychus urticae; resistance

\begin{abstract}
Streszczenie
Przędziorek chmielowiec jest ważnym szkodnikiem sadów jabłoniowych. Jednymi z powszechnie stosowanych akarycydów przeciwko dorosłym stadiom tego fitofaga są preparaty z grupy METI (mitochondrial electron transport inhibitors - inhibitory mitochondrialnego transportu elektronów). Celem badań była ocena występowania zjawiska odporności przędziorków w sadach jabłoniowych, w których zarejestrowano symptomy zmniejszonej skuteczności niektórych akarycydów w odniesieniu do przędziorka chmielowca. Wybrano siedem różnych lokalizacji w Polsce i przetestowano w warunkach laboratoryjnych zarejestrowane w Polsce akarycydy z grupy METI (Magus 200 SC, Ortus 05 SC, Sanmite 20 WP). Zespoły osobników pochodzące z niektórych lokalizacji cechowała wysoka odporność, porównywalna z odpornością osobników pochodzących z hodowlanej rasy odpornej o nazwie Akita.
\end{abstract}

Słowa kluczowe: przędziorek chmielowiec; Tetranychus urticae; odporność

$\overline{\text { Instytut Ogrodnictwa }}$

Konstytucji 3 Maja 1/3, 96-100 Skierniewice

damian.gorzka@inhort.pl 


\section{Wstęp / Introduction}

Roślinożerne roztocze w sadach jabłoniowych stanowią jedną $\mathrm{z}$ największych i najbardziej powszechnych grup szkodników (Putman 1955; Van de Vrie i wsp. 1975). Szybki rozwój, duża płodność oraz szerokie spektrum roślin żywicielskich, w tym także uprawnych, sprawiają, że szkodniki te powodują często znaczące straty $\mathrm{W}$ produkcji roślinnej. Do jednego $\mathrm{z}$ najbardziej znanych roztoczy należących do rodziny przędziorkowatych (Tetranychidae) należy przędziorek chmielowiec (Tetranychus urticae, Koch) - ważny szkodnik w uprawach jabłoni (Van de Vrie 1985). Dynamiczny wzrost jego liczebności zachodzi szczególnie szybko w okresach długiej, suchej i upalnej pogody. W tej sytuacji konieczne jest często stosowanie kilku zabiegów redukujących wielkość jego populacji.

Jednymi $\mathrm{z}$ powszechnie stosowanych akarycydów przeciwko dorosłym stadiom tego fitofaga są środki z grupy METI (mitochondrial electron transport inhibitors inhibitory mitochondrialnego transportu elektronów). Wieloletnie i wielokrotne opryskiwanie preparatami o takim samym mechanizmie działania, może powodować selekcje ras odpornych szkodnika na stosowane przeciwko niemu środki ochrony roślin (Cranham i Halle 1985; Scott 1990; Motoba i wsp. 2000; Davine i wsp. 2001; Nauen i wsp. 2001; Stumpf i Nauen 2001; Leeuwen i wsp. 2005). Od kilku lat także w niektórych rejonach Polski, obserwowano obniżenie skuteczności akarycydów z grupy METI (Maciesiak i Olszak 2010).

Podjęto badania, których celem była ocena powszechności występowania zjawiska odporności przędziorka chmielowca zasiedlającego sady jabłoniowe, usytuowane w różnych regionach Polski.

\section{Materiały i metody / Materials and methods}

Badania prowadzono w latach 2011-2012. W wytypowanych sadach jabłoniowych, w 2011 roku zebrano osobniki dorosłe, nimfy oraz jaja T. urticae w ilości pozwalającej na prowadzenie hodowli tego fitofaga w warunkach laboratoryjnych. Były to lokalizacje: Skierniewice (29-letni sad, odmiana Champion), Głuchowo (13-letni sad, odmiana Gala), Miłobądz (4-letni sad, odmiana Champion), Trzylatków, Józefów (6-letni sad, odmiana Champion), Dąbrowice (6-letni sad, odmiana Golden Delicious), Bartodzieje (18-letni sad, odmiana Ligol) (rys. 1). Przędziorki do badań pobierano z liści jabłoni przywiezionych z wybranych sadów na przełomie sierpnia i września. Analizę skuteczności działania wybranych akarycydów wykonywano w warunkach laboratoryjnych. Do testów nad przeżywalnością przędziorka chmielowca wybrano trzy zarejestrowane akarycydy $\mathrm{z}$ grupy METI: Magus 200 SC (fenazachina), Ortus 05 SC (fenpiroksymat), Sanmite 20 WP (pirydaben). Testy wykonano na liściach jabłoni umieszczonych w specjalnie przygotowanych szalkach Petriego wyścielonych bibułą nasączoną wodą. Na tak przygotowane liście nanoszono po 10 osobników dorosłych przędziorka chmielowca. Każdą kombinację (preparat) testowano w 4 powtórzeniach (40 osobni- ków). Nanoszenie preparatów na liście i znajdujące się na nich przędziorki przeprowadzono w wieży Pottera firmy Burkard Scientific. Dawka na hektar przeliczana była do 11 wody, z którego pobierano $2 \mathrm{ml}$ roztworu. Po aplikacji preparatów obserwacje nad przeżywalnością przędziorków prowadzono w komorze klimatycznej $\left(25^{\circ} \mathrm{C}\right.$, 16L:8D oraz $65 \%$ wilgotność względnej). Śmiertelność oceniano po 72 godzinach. Śmiertelność (przeżywalność) osobników zebranych W sadach porównywano $\mathrm{Z}$ hodowanymi w laboratorium rasami: GSS - wrażliwą na akarycydy z grupy METI oraz Akita - odporną na tę grupę środków.

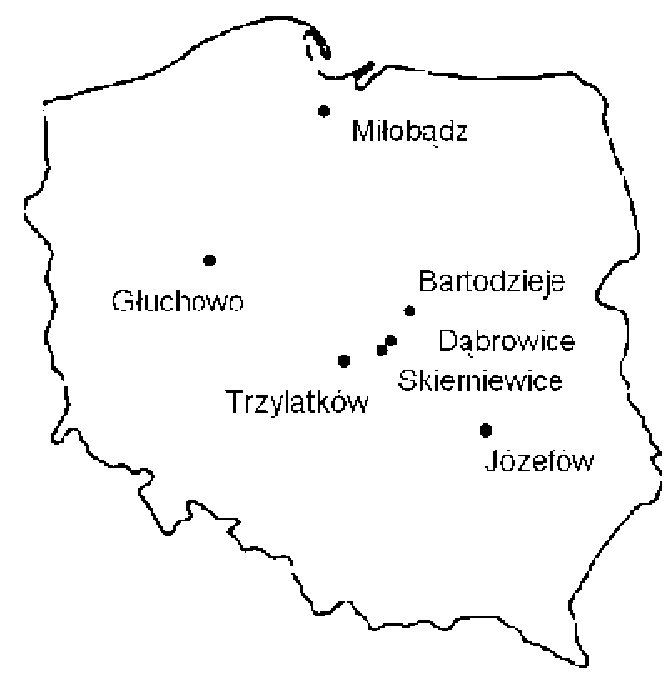

Rys. 1. Rozmieszczenie lokalizacji, z których pobierano materiał do badań

Fig. 1. Distribution location of the collected material for research

Wyniki opracowano statystycznie za pomocą analizy wariancji (ANOVA). Istotność różnic pomiędzy średnimi oceniono za pomocą testu Newmana-Keulusa przy poziomie istotności $\mathrm{p}=0,05$. Analizy przeprowadzono w programie STATISTICA v.10.

\section{Wyniki i dyskusja / Results and discussion}

Przędziorek chmielowiec to obok przędziorka owocowca jeden $\mathrm{z}$ najbardziej uciążliwych szkodników upraw sadowniczych. W warunkach klimatycznych Polski liczba pokoleń w sezonie wegetacyjnym waha się od 4 do 6 . W sprzyjających temperaturach $\left(25-30^{\circ} \mathrm{C}\right)$, co ma często miejsce późną wiosną i latem, czas rozwoju jednego pokolenia skraca się do 10 , a nawet 8 dni. Zwiększenie tempa rozwoju i wzrost liczby pokoleń $\mathrm{z}$ jednoczesną koniecznością zwiększania liczby zabiegów stanowią sytuację sprzyjającą selekcji osobników odpornych. Celem badań nie było jednak odtworzenie historii ochrony jabłoni przed tym szkodnikiem w poszczególnych obiektach badawczych (sadach), tylko ocena istniejącego stanu odporności gatunku. Oczywiście proces ten może przebiegać w różnych sadach z różną intensywnością i szybkością, co jest uwarunkowane wieloma czynnikami. Na podstawie uzyskanych danych liczbowych stwierdzono, że w przy- 


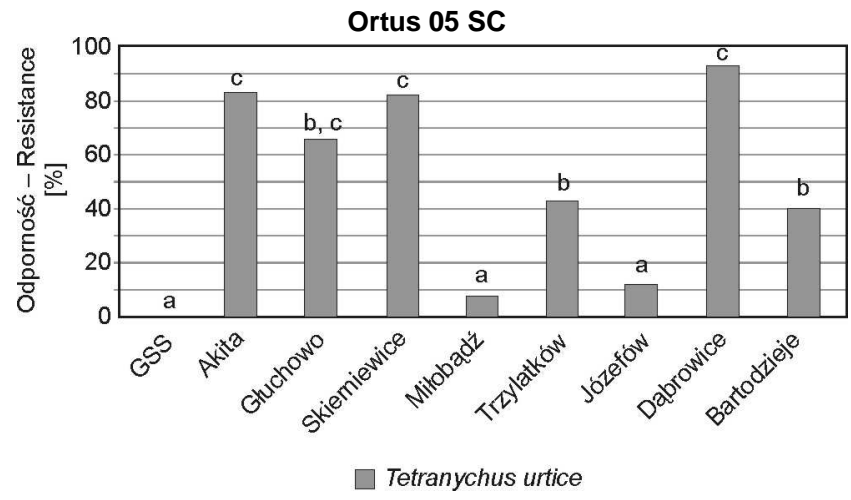

Rys. 2. Odporność osobników przędziorka chmielowca na preparat Ortus 05 SC. Różne litery nad słupkami wskazują na istotność różnic

Fig. 2. Two spotted spider mite individuals resistance to product Ortus 05 SC. Different letters above the bars indicate significance of differences

Magus 200 SC

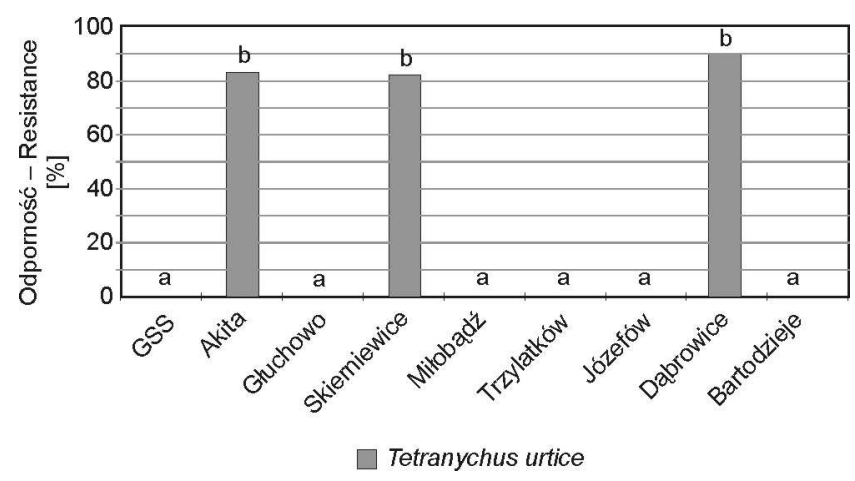

Rys. 3. Odporność osobników przędziorka chmielowca na preparat Magus 200 SC. Różne litery nad słupkami wskazują na istotność różnic

Fig. 3. Two spotted spider mite individuals resistance to product Magus 200 SC. Different letters above the bars indicate significance of differences

\section{Sanmite 20 WP}

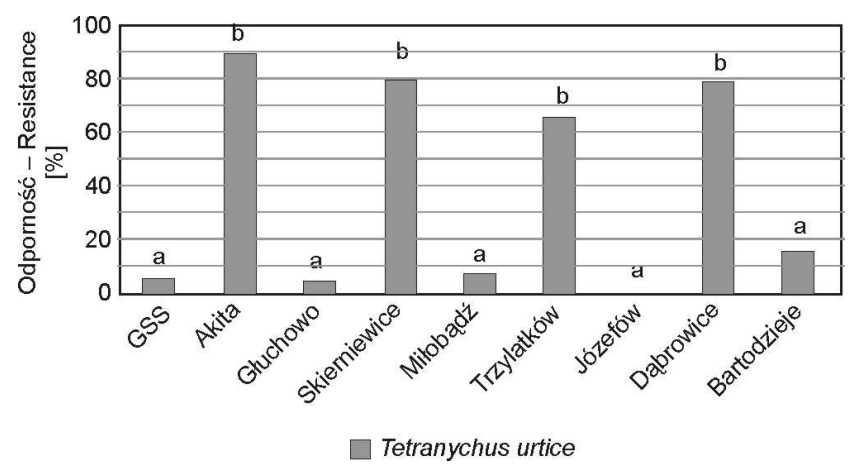

Rys. 4. Odporność osobników przędziorka chmielowca na preparat Sanmite 20 WP. Różne litery nad słupkami wskazują na istotność różnic

Fig. 4. Two spotted spider mite individuals resistance to product Sanmite 20 WP. Different letters above the bars indicate significance of differences padku zastosowania preparatu Ortus 05 SC osobniki T. urticae pochodzące z sadów: Dąbrowice, Skierniewice wykazały poziom odporności, równy lub nawet wyższy niż poziom odporności osobników hodowlanej rasy odpornej Akita. Znaczący poziom odporności tego szkodnika stwierdzono także wśród osobników pochodzących z sadów: Głuchowo, Bartodzieje i Trzylatków. Natomiast osobniki wywodzące się z populacji pozyskanej z sadów: Józefów i Miłobądz charakteryzowały się wrażliwością bliską wrażliwości hodowanej w laboratorium rasy - GSS, wyjątkowo wrażliwej na stosowane akarycydy (rys. 2). Z kolei wyniki uzyskane $\mathrm{w}$ trakcie testowania odporości przędziorka chmielowca z preparatem Magus 200 SC wykazały, że osobniki pochodzące $\mathrm{z}$ populacji pozyskanych $\mathrm{z}$ sadów Dąbrowice i Skierniewice cechowały się taką samą odpornością, jak osobniki z laboratoryjnej rasy odpornej - Akita. Przędziorki pochodzące z pozostałych sadów (Głuchowo, Miłobądz, Trzylatków, Józefów, Bartodzieje) wykazały taki sam poziom wrażliwości, jak osobniki pobrane $\mathrm{z}$ hodowanej w laboratorium linii GSS bardzo wrażliwej na METI akarycydy (rys. 3). Nieco inne wyniki otrzymano w trakcie testowania poszczególnych populacji z użyciem preparatu Sanmite 20 WP (rys. 4). Odpornością na poziomie zbliżonym do poziomu odporności rasy Akita (odporna rasa hodowlana) wykazały się osobniki wywodzące swój „rodowód” z sadu w Skierniewicach, Dąbrowicach i Trzylatkowie. Wrażliwość osobników wywodzących się z pozostałych sadów była na poziomie laboratoryjnej rasy wrażliwej GSS. Odporność przędziorka chmielowca na akarycydy z grupy METI była wykazywana $\mathrm{w}$ różnych rejonach świata, w których stosowano akarycydy z grupy METI, m.in. w: Wielkiej Brytanii, Korei Południowej, Niemczech (Davine i wsp. 2001). Informacje o niezadowalających rezultatach zabiegów wykonanych akarycydami z grupy METI znajdują się także w opracowaniu Maciesiak i Olszak (2010), z tym że dotyczą one innego ważnego gatunku roztocza roślinożernego, jakim jest przędziorek owocowiec (Panonychus ulmi). Odporność różnych populacji T. urticae na niektóre preparaty badano na Cyprze (Vassiliou i Kitsis 2013). Największy poziom odporności na przędziorki stwierdzono wówczas wśród polowej populacji zasiedlającej pomidory. Znacząca odporność $T$. urticae na niektóre z inhibitorów mitochondrialnego transportu elektronów wykazał także Nauen i wsp. (2001). Ponieważ obydwa gatunki roztoczy roślinożernych mogą występować jednocześnie w tych samych sadach i na tych samych drzewach, postanowiono sprawdzić, jaka jest skuteczność akarycydów z grupy METI (inhibitory mitochondrialnego transportu elektronów) w odniesieniu do ruchomych stadiów przędziorka chmielowca. Jest to tym bardziej uzasadnione, że w późniejszych okresach sezonu wegetacyjnego (lipiec, sierpień), kiedy panują stosunkowo wysokie temperatury, szkodnik ten może stanowić większe zagrożenie niż przędziorek owocowiec. Proces selekcji ras odpornych w przypadku szkodników takich, jak przędziorki, może być szczególnie szybki biorąc pod uwagę wielkość populacji, tempo rozwoju oraz liczbę pokoleń w sezonie wegetacyjnym (w Polsce w warunkach polowych 5-6 pokoleń). Wielkość populacji zależy od ich zagęszczenia w przeliczeniu na 1 liść, ale jeśli przyjmie się teoretycznie, 
że na jednym 5-letnim drzewie jabłoni jest średnio około 5000 liści i na każdym z nich występuje po 5 przędziorków (próg zagrożenia), to $\mathrm{w}$ nowoczesnych sadach $\mathrm{z}$ liczbą 2500 drzew/ha liczebność tego szkodnika może wynieść ponad 62 miliony osobników. Przy tak wielkich populacjach i dużej zmienności osobniczej, czynniki selekcyjne o działaniu totalnym mogą szczególnie szybko prowadzić do „powstania” ras odpornych. Dlatego w strategii zwalczania tego typu szkodników szczególnie ważne jest przestrzeganie reguł działań antyodpornościowych, wśród których jedną z podstawowych jest przemienne stosowanie preparatów $\mathrm{z}$ różnych grup chemicznych.

\section{Wnioski / Conclusions}

1. Wykazano zróżnicowanie odporności (wrażliwości) badanych populacji na testowane środki o tym samym mechanizmie działania.

2. W przypadku preparatu Ortus 05 SC znaczącą odporność lub co najmniej obniżoną wrażliwość wykazały osobniki z sadów Dąbrowice, Skierniewice, Głuchowo, Trzylatków i Bartodzieje.

3. W przypadku preparatu Magus 200 SC bardzo wysoką odporność wykazały osobniki pochodzące $\mathrm{z}$ sadów Skierniewice i Dąbrowice.

4. Odporność na preparat Sanmite $20 \mathrm{WP}$ stwierdzono jedynie w sadach: Skierniewice, Dąbrowice i Trzylatków.

5. Na zróżnicowanie odporności w poszczególnych sadach miały wpływ wcześniejsze programy ich zwalczania (stosowane środki).

6. W celu skutecznej ochrony roślin przed przędziorkami należy wykonywać częste badania skryningowe nad selektywnością stosowanych przeciw nim środków ochrony roślin.

Publikacja wykonana w ramach projektu rozwojowego NR 12-0081-10/2010 dofinansowanego przez Narodowe Centrum Badań i Rozwoju.

\section{Literatura / References}

Cranham J.E., Halle W. 1985. Pesticide resistance in tetranychidae. p. 405-421. In: „World Crop Pests, Spider Mites, Volume 1b” (W. Halle, M.W. Sabelis, eds). Elsevier, Amsterdam-Oxford-New York-Tokyo, 458 pp.

Putman W.L. 1955. Bionomics of Stethorus punctillum Weise (Coleoptera: Coccinelidae) in Ontario. Can. Entomol. 87: 9-33.

Davine G.J., Barber M., Denholm J. 2001. Incidence and inhertinance of resistance to METI - acaricides in European strains of the twospotted spider mite (Tetranychus urticae) (Acari: Tetranychidae). Pest Manage. Sci. 57: 443-448.

Maciesiak A., Olszak R.W. 2010. Wzrost zagrożenia sadów jabłoniowych przez przędziorka owocowca (Panonychus ulmi, Koch) przyczyny niepowodzeń zwalczania. [Increase of threat of the apple orchards by European red spiker mite (Panonychus ulmi, Koch) - adversity in control]. Prog. Plant Prot./Post. Ochr. Roślin 50 (3): 1292-1296.

Motoba K., Nishizawa H., Suzuki T., Hamaguchi H., Uchida M. 2000. Species specific detoxifcation metabolism of fenpyroximate, a potential acaricide. Pest. Biochem. Physiol. 67: 73-84.

Nauen R., Stumpf N., Elbert A., Zebitz C.P.W., Kraus W. 2001. Acaricide toxicity and resistance in larvae of different strains of Tetranychus urticae and Panonychus ulmi (Acari: Tetranychidae). Pest Manage. Sci. 57: 253-261.

Scott J.G. 1990. Investigating mechanisms of insecticide resistance: methods, strategies, and pitfalls. p. 39-57. In: „Pesticide Resistance in Arthropods" (R.T. Roush, B.E. Tabashnik, eds). New York, Chapman \& Hall, 342 pp.

Stumpf N., Nauen R. 2001. Cross-resistance, inheritance and biochemistry of METI-acaricide resistance in Tetranychus urticae (Acari: Tetranychidae). J. Econ. Entomol. 94: 1577-1583.

Van Leeuwen T., Van Pottelberge S., Tirry L. 2005. Comparative acaricide susceptibility and detoxifying enzyme activity in a field collected resistant and susceptible strain of Tetranychus urticae. Pest Manage. Sci. 61: 499-507.

Van Se Vrie M., McMurtry J.A., Huffaker C.B. 1985. Biology of tetranyhid mites species occuring on apple. p. 312-314. In: „World Crop Pests, Spider Mites, Volume 1b (W. Halle, M.W. Sabelis, eds). Elsevier Amsterdam-Oxford-New York-Tokyo, 458 pp.

Vassiliau V.A., Kitsis P. 2013. Acaricide resistance in Tetranychus urticae (Acari: Tetranychidae) population from Cyprus. J. Econ. Entomol. 106 (4): 1848-1854. 